\title{
Perspective \\ Obesity and Cancer: Potential Mediation by Dysregulated Dietary Phosphate
}

\author{
Ronald B. Brown (D)
}

check for

updates

Citation: Brown, R.B. Obesity and Cancer: Potential Mediation by Dysregulated Dietary Phosphate. Obesities 2022, 2, 64-75. https:// doi.org/10.3390/obesities2010007

Academic Editor: Carmine Finelli

Received: 27 December 2021

Accepted: 28 January 2022

Published: 2 February 2022

Publisher's Note: MDPI stays neutral with regard to jurisdictional claims in published maps and institutional affiliations.

Copyright: (c) 2022 by the author. Licensee MDPI, Basel, Switzerland. This article is an open access article distributed under the terms and conditions of the Creative Commons Attribution (CC BY) license (https:// creativecommons.org/licenses/by/ $4.0 /)$.
School of Public Health Sciences, University of Waterloo, Waterloo, ON N2L3G1, Canada; r26brown@uwaterloo.ca

\begin{abstract}
Next to smoking, obesity is the second leading preventable risk factor for cancer, but increasing rates of obesity and overweight are estimated to overtake smoking as the leading preventable cancer risk factor. Few research studies have investigated the dysregulated endocrine metabolism of dietary phosphate as a potential mediating factor in the association of obesity with cancer. Phosphate toxicity, the accumulation of excess phosphate in the body from dysregulated phosphate metabolism, is associated with tumorigenesis. High levels of hormones that regulate phosphate metabolism, such as parathyroid hormone and fibroblast growth factor 23 , are also associated with obesity, providing a potential link between obesity and phosphate toxicity. Increased dietary intake of inorganic phosphate is linked to excessive consumption of foods processed with phosphate additives, and consumption of ultra-processed foods is associated with an increase in the incidence of obesity. Sugar-sweetened beverages provide the single largest source of sugar and energy intake in the U.S. population, and colas containing phosphoric acid are associated with tumorigenesis, suggesting another potential connection between obesity and cancer. Furthermore, dietary phosphate is positively correlated with increases in obesity, central obesity, and metabolic syndrome. The present perspective article proposes that dysregulated dietary phosphate potentially mediates the association of obesity with cancer.
\end{abstract}

Keywords: obesity; cancer; tumorigenesis; dysregulated phosphate; phosphate toxicity; FGF23; parathyroid hormone; vitamin D; phosphoric acid; ultra-processed food

\section{Introduction}

The World Health Organization (WHO) defined obesity as "abnormal or excessive fat accumulation that may impair health," caused by "an energy imbalance between calories consumed and calories expended" [1]. Noting that "overweight and obesity, as well as their related noncommunicable diseases, are largely preventable," WHO recommended reducing obesity and overweight through supportive environments and communities that provide easier access to regular physical activity, with more affordable and greater availability of healthy food choices.

Next to smoking, obesity is the second leading preventable risk factor for cancer, but increasing rates of obesity and overweight are estimated to overtake smoking as the leading preventable cancer risk factor within the next two decades [2]. Yet, much of the population remains unaware of the association of obesity with cancer [3]. Evidence is sufficiently strong to link obesity with at least 13 sites of cancer: esophagus, stomach, colorectum, liver, gallbladder, pancreas, breast, uterus, ovary, kidney, meninges, thyroid, and white blood cells [4]. Paradoxically, a higher bodyweight has also been associated with reduced cancer risk-an obesity paradox that some researchers suggest may be related to selection bias from reliance on body mass index (BMI), which does not measure fat mass and fat-free mass [5].

Hypotheses of the pathophysiological mechanisms linking obesity and cancer commonly investigate hormonal and enzyme dysregulation of glucose and lipid metabolism [6]. For example, obesity in humans is associated with higher levels of the hepatic protein kinase 
$\mathrm{C} \beta$ (PKC $\beta$ ), which negatively regulates glycogenesis [7]. Dysregulated PKC $\beta$ is common in many cancers and may be implicated in cancer development. Additionally, dysregulated inositol synthesis in Drosophila melanogaster fed a high-sucrose diet is a potential model for similar inositol abnormalities in human cancer and obesity [8]. However, few research studies have investigated dysregulated endocrine metabolism of dietary phosphate as a potential mediating factor in the association of obesity with cancer.

The present perspective article reviews epidemiologic and pathophysiologic relationships between obesity, unhealthy food choices associated with dysregulated dietary phosphate, and tumorigenesis in obesity-related cancers. Articles from the research literature were selected and analyzed in this perspective paper using a grounded theory method [9]. Keyword searches were conducted in Google, Google Scholar, PubMed, Scopus, and other online sources. Comparative analyses of the literature findings were synthesized into themes and formed into causative and associative relationships linking obesity, dysregulated phosphate metabolism, and cancer. All the findings and proposals in the present perspective article are grounded in evidence, and offer the present author's insights and point of view.

\section{Phosphate Metabolism}

\subsection{Phosphate Functions}

The dietary mineral phosphorus, often found in chemical combination with oxygen as phosphate $\left(\mathrm{PO}_{4}\right)$, is an essential micronutrient with a dietary reference intake (DRI) of $700 \mathrm{mg} /$ day for adults [10]. Phosphate performs a wide variety of functions in the human body [11], as shown in Figure 1. Bones and teeth contain 85\% of total body phosphate. Inorganic phosphate $(\mathrm{Pi})$ forms hydroxyapatite with calcium, which mineralizes the extracellular matrix of bone. The lipid bilayers of cell membranes contain phosphate, and phosphate is a component in nucleic acids, deoxyribonucleic acid (DNA), and ribonucleic acid (RNA). Energy is derived from the metabolism of adenosine triphosphate (ATP) and adenosine diphosphate (ADP). Phosphate also acts as a urinary buffer, and many enzymatic reactions involve inorganic phosphate.

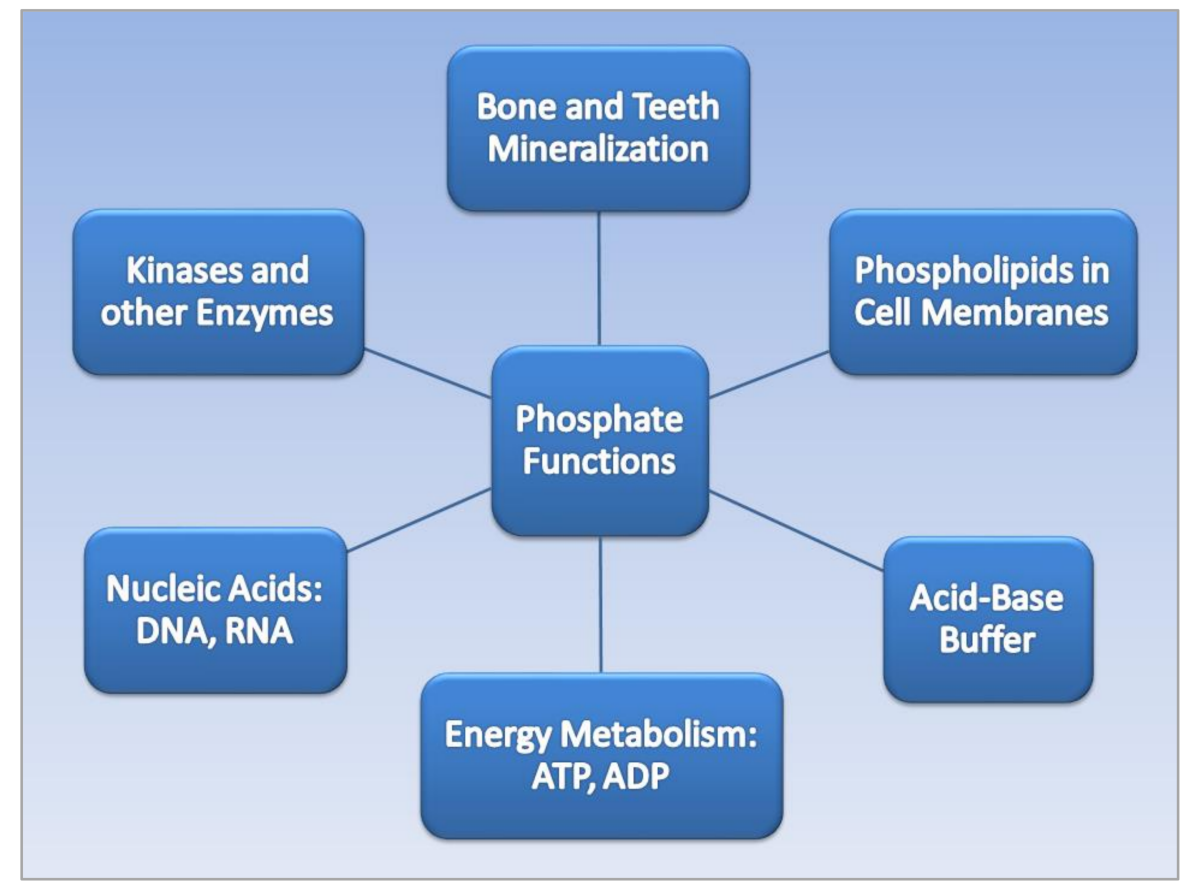

Figure 1. Phosphate functions in the human body. 


\subsection{Phosphate Regulation and Dysregulation}

Serum Pi is regulated by a sensitive network of endocrine hormones that form a bone-kidney-parathyroid-intestine axis, as shown in Table 1. Ref. [12]. Pi absorption in the intestines occurs mainly through type II sodium-dependent phosphate cotransporters, and intestinal absorption is regulated by bioactive vitamin D3 released by the kidneys, $1,25(\mathrm{OH})_{2} \mathrm{D}_{3}$, or calcitriol. The kidneys regulate serum Pi through reabsorption largely in the renal proximal tubule. Fibroblast growth factor 23 (FGF23) released from osteocytes in the bones, together with parathyroid hormone (PTH) from the parathyroid glands, reduce high serum Pi levels by inhibiting kidney reabsorption of Pi and increasing Pi urinary excretion [13]. PTH also increases the resorption of calcium from bone to maintain serum calcium levels. Excess calcium phosphate formed in the blood serum from dysregulated phosphate metabolism can lead to ectopic calcification deposited throughout the soft tissue [14].

Table 1. Endocrine Regulation of Serum Pi through the Bone-Kidney-Parathyroid-Intestine Axis.

\begin{tabular}{llll}
\hline \multicolumn{1}{c}{ Bone } & \multicolumn{1}{c}{ Kidney } & \multicolumn{1}{c}{ Parathyroid } & \multicolumn{1}{c}{ Intestine } \\
\hline $\begin{array}{l}\text { FGF23 inhibits serum } \\
\text { Pi reabsorption in } \\
\text { kidneys. }\end{array}$ & $\begin{array}{l}\text { Regulates serum Pi } \\
\text { reabsorption and Pi } \\
\text { urinary excretion. }\end{array}$ & $\begin{array}{l}\text { PTH increases serum } \\
\text { calcium through bone } \\
\text { resorption. }\end{array}$ & $\begin{array}{l}\text { Pi absorption from } \\
\text { dietary sources. }\end{array}$ \\
\hline $\begin{array}{l}\text { Increases Pi urinary } \\
\text { excretion. }\end{array}$ & $\begin{array}{l}\text { calcitriol from } \\
\text { vitamin } \mathrm{D}_{3} \text { increases } \\
\text { Pi intestinal } \\
\text { absorption. }\end{array}$ & $\begin{array}{l}\text { Increases Pi urinary } \\
\text { excretion with FGF23. }\end{array}$ & $\begin{array}{l}\text { Type II } \\
\text { sodium-dependent } \\
\text { phosphate } \\
\text { cotransporters. }\end{array}$ \\
\hline
\end{tabular}

\section{Phosphate Toxicity and Tumorigenesis}

Phosphate toxicity, the accumulation of excess phosphate in the body from dysregulated phosphate metabolism, is associated with tumorigenesis [15]. Excessive cell growth during tumor promotion and progression is stimulated by the uptake of excess phosphate into cellular ribosomal RNA, and suppressed uptake of phosphorus within nuclear RNA was shown to delay carcinogenesis in precancerous tissue [16]. High levels of phosphate within the tumor microenvironment have been found to stimulate cell signaling in tumorigenesis [17] and tumor neovascularization [18]. Moreover, high phosphate levels in patients with hyperphosphatemia are associated with chromosome instability and increased parathyroid cell proliferation-further investigations of a direct effect of phosphate on DNA damage are needed [19]. Additionally, high extracellular levels of Pi have been linked to cancer progression through metastasis [20].

Cancer cells absorb and sequester large amounts of inorganic phosphate from the tumor extracellular microenvironment through sodium-phosphate cotransporters, which were overexpressed in cancer cells of the breast, lung, ovaries, and thyroid gland [21,22]. Levels of inorganic phosphate were up to twice as high in lung and colon tumor cells compared to normal cells [23], and high dietary phosphate levels were found to increase skin cancer growth in an animal model [24]. As well, lung tumorigenesis was stimulated in mice fed high levels of dietary inorganic phosphate [17]. Cancer in humans was also associated with higher serum phosphate levels in adults, with the exception of reproductive cancers in females, which may be due to phosphate shifting into the reproductive tissue for rapid growth $[25,26]$.

More recently, $\mathrm{H}^{+}$-dependent Pi transporters in breast cancer cells were found to transport high concentrations of $\mathrm{Pi}$ at five-times the rate of sodium-phosphate cotransporters [27]. Patients with high levels of FGF23, which regulates Pi metabolism, had reduced overall survival compared to patients with low levels [28], and FGF23 levels were significantly higher in patients with urothelial carcinoma of the bladder and upper urinary tract compared to normal controls [29]. Additionally, compared to men with benign prostate hyperplasia, men with prostate cancer had higher levels of PTH, which also regulates Pi metabolism [30]. 
High serum PTH levels are associated with all-cause mortality in U.S. adults [31], and patients with primary hyperparathyroidism had significantly higher risks of diagnosis with cancers of the breast, skin, and kidney [32].

\section{Phosphate Toxicity and Obesity}

The same hormones that regulate phosphate metabolism are also associated with obesity, providing a transitive link between obesity and phosphate toxicity. For example, high serum FGF23 was associated with increased fat mass in a cohort of elderly white people with normal renal function [33]. Participants in the study who had the highest levels of FGF23 also had a significantly higher risk for overweight compared to individuals with the lowest FGF23 levels. A 10\% increase in FGF23 in the cohort was associated with a $3 \%$ increase in body weight and BMI and a $2 \%$ increase in waist circumference (WC) and waist-hip ratio (WHR). Additionally, a 10\% increase in FGF23 in males was associated with a $4 \%$ increase in total body fat mass and trunk fat mass.

Hyperparathyroidism is commonly found in high-grade obesity, and higher serum levels of PTH were found in $72 \%$ of bariatric patients with severe obesity who underwent laparoscopic sleeve gastrectomy (LSG) [34]. Patients' PTH levels dropped along with BMI following surgery, likely related to a lower caloric density and volume of food intake following LSG [35]. These findings imply that diet is an etiological factor in hyperparathyroidism related to obesity, which provides an additional transitive link between obesity and phosphate toxicity from excessive dietary phosphate intake. Higher concentrations of serum PTH were also positively associated with obesity in females with metabolic abnormalities, while levels of $25(\mathrm{OH}) \mathrm{D} 3$, which are converted to calcitriol to increase phosphate absorption in the intestines, were inversely associated with obesity in males with metabolic abnormalities [36].

Obesity is often associated with inadequate intake of micronutrients such as calcium, magnesium, copper, iron, and zinc, but a recent analysis of the US National and Health Nutrition Examination Survey (NHANES) 2007-2014 found that phosphorus dietary intake in adults, along with sodium, was positively associated with BMI [37]. Of relevance, type II sodium-phosphate cotransporters $(\mathrm{Na} / \mathrm{Pi}-2 \mathrm{~b})$ and type III inorganic phosphate transporters (Pit-1 and Pit2) are found in the salivary glands, and obese and overweight children were found to have significantly higher saliva levels of phosphate than normal-weight children, despite having normal serum phosphate levels [38]. A plausible mechanism accounting for higher saliva phosphate in obese and overweight children could be related to increased salivary gland cotransport of phosphate from higher levels of ingested dietary phosphate-more investigations are needed in this area.

Hypophosphatemia has also been linked to high BMI, but rather than resulting from low dietary phosphate intake or phosphate losses in urine, low serum phosphate is most frequently caused by a transcellular shift of internal phosphate [39]. Because dietary carbohydrates require phosphorylation of glucose compounds during glycolysis, excessive intake of carbohydrates releases increased levels of insulin which may cause phosphate to shift from extracellular blood serum to liver and skeletal muscle cells during metabolism of a heavy load of sugars [40]. Moreover, abdominal obesity is a part of metabolic syndrome [41], and high serum levels of catecholamines in metabolic syndrome also increase metabolic glycolysis of sugars, which further contributes to a phosphate transcellular shift that lowers serum phosphate levels.

A paradoxical relationship also exists in the association of obesity with a lower risk of breast cancer in premenopausal women compared to postmenopausal women [42]. The mid-luteal phase of the menstrual cycle is when the uterus undergoes growth [43], and women self-reported consuming more animal-based foods during this phase [44]. Animal-based foods contain high levels of protein and phosphorus, which are needed to support the monthly growth of the uterus. The need for more phosphorus during the menstrual cycle could mitigate the risk of phosphate toxicity associated with heavy dietary 
phosphate intake in obese premenopausal women, which would lower the risk of breast cancer compared to obese postmenopausal women.

Before closing this section on phosphate toxicity and obesity, it should be mentioned that low levels of vitamin D are consistently linked with obesity and with cancer, but researchers found that "the mediating role of vitamin D in the biological pathways linking obesity and cancer is low" [45]. On the other hand, high serum Pi can signal endocrinecontrolled reductions in the renal biosynthesis of calcitriol (bioactive vitamin D), thus lowering dietary phosphate intestinal absorption. In other words, low vitamin D appears to be a consequence rather than a cause of dysregulated Pi metabolism in obesity and cancer.

\section{Pi, Ultra-Processed Food, and Obesity}

Increased dietary intake of inorganic phosphates is linked to excessive consumption of processed foods, but the actual amount of phosphate intake from processed foods is often unknown because food labels do not list the amount of inorganic phosphates in food additives [46]. Inorganic phosphate is effectively absorbed in the body, and people with a lower socioeconomic status (SES) consume the highest amount of processed and convenience foods with added phosphate [47]. Of relevance, obesity in high-income countries is more prevalent among people with a lower SES [48], inferring that a lower SES mediates the association of greater Pi intake with high consumption of processed foods by obese people.

Additionally, a recent prospective cohort study showed that consumption of ultraprocessed foods was associated with a $79 \%$ increase in the incidence of obesity measured by BMI and a $30 \%$ increase in the incidence of abdominal obesity measured by WC [49]. Ultra-processed foods in the study included breads, snacks, desserts, frozen and ready-toeat meals, beverages, breakfast cereals, spreads, and sauces. Over a median of 5.6 years, ultra-processed food consumption was associated with a $5 \%$ or higher risk of increasing BMI, WC, and body fat percentage in the cohort. Another study found that a $10 \%$ increase in ultra-processed food consumption was associated with a 10\% and higher risk of breast cancer and overall cancer [50]. Animal products with greater phosphorus absorption also "contribute to the poor dietary habits linked with the rising rate of obesity in the USA", with every $0.5 \mathrm{mg} / \mathrm{dL}$ increase in serum Pi levels associated with a $2 \%$ increase in odds of obesity [51].

Participants in a randomized controlled trial ate as much food as they wanted after being assigned to either an unprocessed diet or an ultra-processed diet, served in meals with equivalent amounts of nutrients and calories [52]. Over two weeks, the unprocessed diet caused participants to eat less food, fewer calories, and lose a mean weight of $0.9 \mathrm{~kg}$ compared to the ultra-processed diet which caused participants to eat more food, additional calories, and gain a mean weight of $0.9 \mathrm{~kg}$. Additional calories consumed in ultra-processed foods were from carbohydrates and fats. Results reversed when the participants switched diets. More studies are needed to measure the dietary intake of phosphorus from ultraprocessed diets compared to unprocessed diets.

\section{Soft Drinks, Phosphoric Acid, and Obesity}

Sugar-sweetened beverages provide the single largest source of sugar and energy intake in the U.S. population [53] and also provide the largest source of sugar intake in the Mexican population [54]. Obesity and weight gain associated with greater consumption of sugar-sweetened beverages was found in systematic reviews of epidemiological and experimental evidence in 2006 [55], in a majority of reviewed studies of children and adolescents in 2015 [56], and in studies of adults and children in 2017 [57]. Another systematic review and meta-analysis found that obesity was associated with artificially sweetened as well as sugar-sweetened beverages [58].

In addition to an increased risk of obesity, a recent meta-analysis of prospective cohort studies found that increased consumption of sugar-sweetened and artificially sweetened beverages was associated with increased all-cause mortality [59]. A cohort study involving 
participants from the European Prospective Investigation into Cancer and Nutrition (EPIC) found an association between a high risk of death from all causes and a high consumption of total, artificially sweetened, and sugar-sweetened beverages [60].

\section{Phosphoric Acid}

Reports in clinical and experimental literature from 1970 to 1997 linked mineral metabolism disorders and neoplasms with soft drinks such as colas that contain phosphoric acid [61]. Consumption of cola soft drinks negatively affected biomarkers of bone, liver, and kidney function in adult male rats [62]. A more recent study found that adult male rats who consumed Pepsi Cola for three months had lower serum levels of vitamin D and calcium but higher levels of phosphorus along with histopathological changes in the liver and kidney tissue compared to a control group [63].

Consumption of phosphoric-acid-containing soft drinks was associated with hypocalcemia in children $[64,65]$ and with elevated serum PTH, hypocalcemia, and hyperphosphaturia in postmenopausal women [66]. Hypocalcemia occurs when phosphate ions from phosphoric acid consumed in cola react with serum calcium ions and precipitate into calcium hydrogen phosphate-followed by a release of PTH that resorbs calcium from bone to restore serum calcium levels [67]. Low bone mineral density in older women was also associated with cola consumption but not with other carbonated beverages, which the researchers attributed to mineral imbalances from the phosphoric acid in cola [68]. High intake of sugar-sweetened beverages containing phosphoric acid was inversely associated with bone health in a recent systematic review and meta-analysis [69], and cola intake was inversely associated with bone mineral density in male adolescents and young adults from the Korea National Health and Nutrition Examination Survey, 2008-2011 [70].

\section{Soft Drinks and Cancer}

Lab results of long-term carcinogenicity bioassays of Coca-Cola consumed by 1999 rats showed an increase in bodyweight and increased incidence of malignant mammary tumors and pancreatic adenomas, with insignificant increases in pancreatic islet cell carcinomas [71] Consumption of sugary drinks, including $100 \%$ fruit juices, was associated with overall cancer and breast cancer risk in a large prospective cohort study [72]. Researchers suggested that the association of cancer with sugary drinks might be partially explained by the relationship of consumption with overweight and obesity, which the researchers attempted to adjust based on BMI. Sugar-sweetened beverage consumption among postmenopausal women was also associated with an increased risk of type I endometrial cancer [73].

More recently, a higher risk of early-onset colorectal cancer among women was associated with higher sugar-sweetened beverage consumption in adolescence and adulthood [74]. A recent meta-analysis of observational studies also found that overall cancer risk and mortality was associated with sugary drink consumption, especially for risk of hepatocellular carcinoma, colorectal cancer, prostate cancer, and risk and mortality for breast cancer [75]. Furthermore, another meta-analysis of observational studies found that artificially sweetened soft drink consumption was associated with an increased risk of liver cancer [76]. Consumption of a combination of sugar-sweetened and artificially sweetened drinks and fruit juices was also associated with an increased risk of liver cancer in a European cohort [77].

In response to the global obesity crisis, artificially sweetened beverages have been proposed as an important part of a healthy diet-yet, evidence of their effectiveness to prevent weight gain and long-term studies of their health effects are lacking for artificially sweetened beverages, which also provide a low nutritional value and contain additive ingredients [78]. Of relevance, artificially sweetened colas contain as much added phosphoric acid as sugar-sweetened colas, and the promotion of artificially sweetened colas could potentially pose a risk of tumorigenesis and other adverse health effects associated with dysregulated phosphate metabolism and phosphate toxicity. Investigations of phosphoric acid and dysregulated dietary phosphate in obesity and cancer should be given 
equal consideration to other dietary factors such as glucose and lipids contained in highly processed foods.

\section{Phosphate Additives and Obesity}

In addition to soft drinks with added phosphoric acid, processed cheese contributes the highest amount of phosphate additives in the American diet, according to an analysis of NHANES 2015-2016 [79]. Other processed foods contributing high amounts of phosphate include bakery products that utilize phosphate for leavening-pies and cakes, rolls and buns, cookies and brownies, doughnuts, sweet rolls, pastries, and tortillas. The foods that contribute the most total phosphate from a combination of natural and additive ingredients are cheese, pizza, whole chicken pieces, reduced-fat milk, eggs and omelets, yeast breads, and cold cuts and cured meats.

An analysis of a biracial cohort, Healthy Aging in Neighborhoods of Diversity across the Life Span (HANDLS), found that cheese and yogurt consumption were associated with an increased risk of central obesity [80]. Increased consumption of cheese and phosphorus intake were also positively correlated with increases in obesity (BMI), central obesity (WC), and metabolic syndrome in a cross-sectional study of participants from NHANES 1999-2004 [81]. Furthermore, a dietary pattern with a low calcium: phosphorus ratio (low calcium and high phosphorus) was also associated with increased obesity measured by Waist to Height Ratio (WHtR) in a Brazilian population [82]. A Japanese study found that patients with schizophrenia, "known to be prone to be overweight," consumed more phosphorus than the general public, and phosphorus consumption was highest in patients with higher BMIs [83]. The researchers suggested high phosphorus intake could be attributed to patients who "often used fast food products."

A study using a mouse model demonstrated that high amounts of dietary inorganic phosphate altered cell signaling and increased tumorigenesis of the lungs [17]. Lead investigator Myung-Haing Chou commented on the study:

"In the 1990s, phosphorus-containing food additives contributed an estimated $470 \mathrm{mg}$ per day to the average daily adult diet," Chou said. "However, phosphates are currently being added much more frequently to a large number of processed foods, including meats, cheeses, beverages, and bakery products. As a result, depending on individual food choices, phosphorus intake could be increased by as much as $1000 \mathrm{mg}$ per day" [84].

If excessive consumption of ultra-processed food is an epidemiological determinant of obesity and cancer, then modification of ultra-processed food intake and a return to dietary patterns emphasizing whole, natural, unprocessed foods, is a viable strategy to prevent these diseases. Nutritional epidemiologist Marian L. Neuhouser recently wrote:

"A shift towards healthy dietary patterns has the potential to curtail the current unsustainable high level of obesity, cardiovascular disease, diabetes mellitus and cancer in the United States and around the globe" [85].

\section{Summary and Future Directions}

The biological pathways linking obesity and cancer proposed in the present paper are summarized in Figure 2-a directed acyclic graph (DAG) [86]. The dashed line in the figure represents an associative relationship between obesity and tumorigenesis in cancer involving suspected factors other than phosphate. This associative relationship is potentially mediated by solid lines representing a pathway of causative links between obesity and dysregulated dietary phosphate and between dysregulated dietary phosphate and tumorigenesis. Mediation by these proposed causative relationships provides the basis to generate testable hypotheses for further investigations of obesity and cancer. 


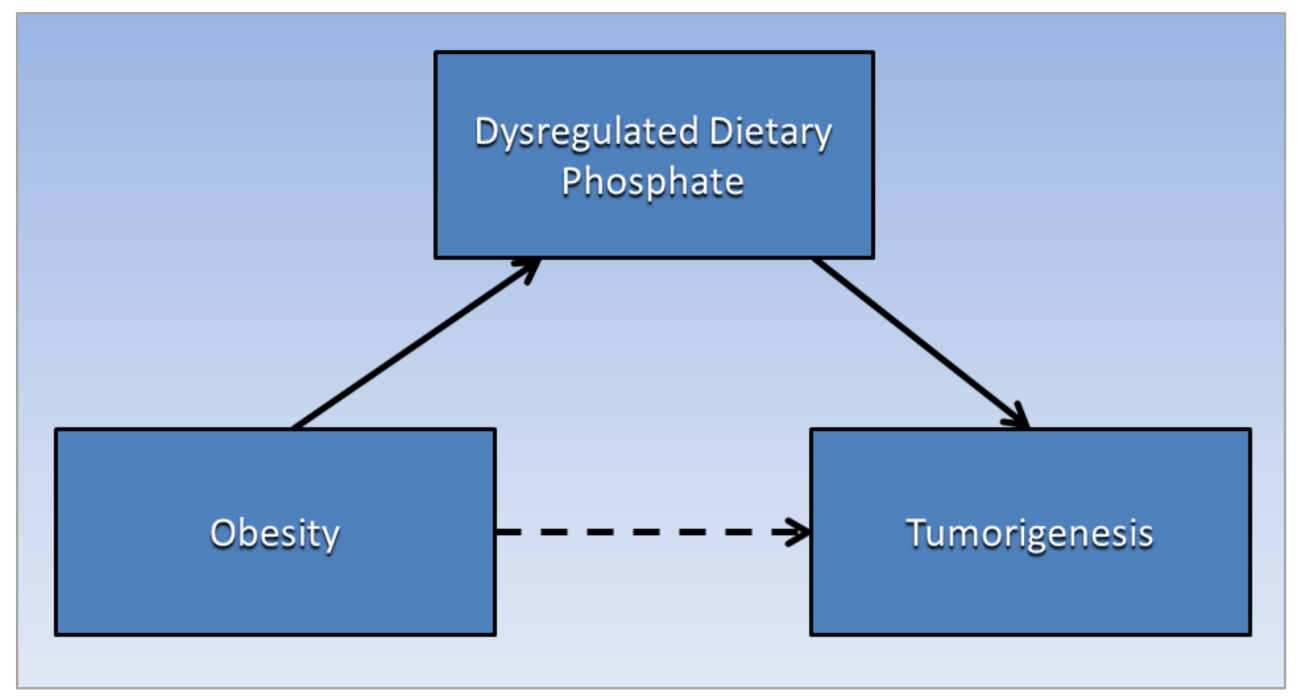

Figure 2. Obesity increases levels of dysregulated dietary phosphate, which mediates the association between obesity and tumorigenesis.

Additionally, conditions comorbid with obesity could contribute to renal damage, thereby increasing the risk of dysregulated phosphate, phosphate toxicity, and associated tumorigenesis discussed in the present paper. Comorbid conditions such as atherogenic dyslipidemia, hypertension, insulin resistance, and type 2 diabetes cause renal damage in obesity through oxidative stress, inflammation, upregulation of the renin-angiotensinaldosterone system, increased activity of the sympathetic nervous system, and endothelial dysfunction [87]. Future research should investigate the biological pathways between obesity-related cancers and comorbid conditions involving impaired kidney function and dysregulation of phosphate metabolism.

Finally, writing in the Lancet in 1996, Schipper et al. [88] proposed a new regulatory model for cancer research. The researchers suggested that dysregulated metabolic pathways linked to the clinical course of cancer are reversible. Supporting evidence provided by the researchers at the time included cancer cell genetic differentiation in treatment for leukemia and recovery from gastric lymphoma related to the eradication of Helicobacter pylori infection. More recently, supporting evidence linking dysregulated phosphate metabolism and cancer appears highly concordant and coherent with the regulatory model. The model can be used to guide future cancer research to test whether modification or reversal of dysregulated phosphate metabolism through dietary interventions can alter the clinical course of cancer. Restricted-phosphate diets are currently used to modify the progression of chronic kidney disease [89], and similar diets should be tested for use in patients with obesity-related cancers.

\section{Conclusions}

In conclusion, the evidence presented in this paper supports an endocrine pathway in which dysregulated dietary phosphate potentially mediates the association of obesity with cancer. Excessive consumption of ultra-processed foods and other foods high in phosphate in obesity increase the intake of inorganic phosphate, phosphoric acid, and other phosphate additives, leading to dysregulated dietary phosphate. In turn, dysregulated dietary phosphate and phosphate toxicity are associated with tumorigenesis. Further studies should investigate the involvement of dysregulated dietary phosphate and impaired kidney function in obesity-related cancers.

Funding: This research received no external funding.

Institutional Review Board Statement: Not applicable.

Informed Consent Statement: Not applicable. 
Conflicts of Interest: The author declares no conflict of interest.

\section{References}

1. who.int. Obesity and Overweight. Available online: https://www.who.int/news-room/fact-sheets/detail/obesity-andoverweight (accessed on 28 November 2021).

2. Cancerresearchuk.Org. When could overweight and obesity overtake smoking as the biggest casue of cancer in the UK? Available online: https: / / www.cancerresearchuk.org/sites/default/files/obesity_tobacco_cross_over_report_final.pdf (accessed on 19 December 2021).

3. Renehan, A.G.; Lloyd, K.; Renehan, I. Awareness of the link between obesity and cancer in UK school curricula. Lancet 2019, 393, 1591-1592. [CrossRef]

4. Lauby-Secretan, B.; Scoccianti, C.; Loomis, D.; Grosse, Y.; Bianchini, F.; Straif, K. Body Fatness and Cancer-Viewpoint of the IARC Working Group. N. Engl. J. Med. 2016, 375, 794-798. [CrossRef] [PubMed]

5. Lee, D.H.; Giovannucci, E.L. The Obesity Paradox in Cancer: Epidemiologic Insights and Perspectives. Curr. Nutr. Rep. 2019, 8, 175-181. [CrossRef]

6. Stone, T.W.; McPherson, M.; Gail Darlington, L. Obesity and Cancer: Existing and New Hypotheses for a Causal Connection. EBioMedicine 2018, 30, 14-28. [CrossRef] [PubMed]

7. Shu, Y.; Hassan, F.; Ostrowski, M.C.; Mehta, K.D. Role of hepatic PKC $\beta$ in nutritional regulation of hepatic glycogen synthesis. JCI Insight 2021, 6, e149023. [CrossRef] [PubMed]

8. Rivera, M.J.; Contreras, A.; Nguyen, L.T.; Eldon, E.D.; Klig, L.S. Regulated inositol synthesis is critical for balanced metabolism and development in Drosophila melanogaster. Biol. Open 2021, 10, bio058833. [CrossRef]

9. Wolfswinkel, J.F.; Furtmueller, E.; Wilderom, C.P.M. Using grounded theory as a method for rigorously reviewing literature. Eur. J. Inf. Syst. 2013, 22, 45-55. [CrossRef]

10. IOM. Dietary Reference Intakes for Calcium, Phosphorus, Magnesium, Vitamin D, and Fluoride; Institute of Medicine Standing Committee on the Scientific Evaluation of Dietary Reference Intakes; National Academy of Sciences: Washington, DC, USA, 1997.

11. Qadeer, H.A.; Bashir, K. Physiology, Phosphate; StatPearls Publishing: Treasure Island, FL, USA, 2021.

12. Brown, R.B. Stress, inflammation, depression, and dementia associated with phosphate toxicity. Mol. Biol. Rep. 2020, 47, 9921-9929. [CrossRef]

13. Saki, F.; Kassaee, S.R.; Salehifar, A.; Omrani, G.H.R. Interaction between serum FGF-23 and PTH in renal phosphate excretion, a case-control study in hypoparathyroid patients. BMC Nephrol. 2020, 21, 176. [CrossRef]

14. Brown, R.B.; Razzaque, M.S. Dysregulation of phosphate metabolism and conditions associated with phosphate toxicity. BoneKEy Rep. 2015, 4, 705. [CrossRef]

15. Brown, R.B.; Razzaque, M.S. Phosphate toxicity and tumorigenesis. Biochim. Et Biophys. Acta (BBA)-Rev. Cancer 2018, 1869, 303-309. [CrossRef] [PubMed]

16. Ward, D.N.; Griffin, A.C. Phosphorus incorporation into nucleic acids and proteins of liver nuclei of normal and azo dye-fed rats. Cancer Res. 1955, 15, 456-461. [PubMed]

17. Jin, H.; Xu, C.-X.; Lim, H.-T.; Park, S.-J.; Shin, J.-Y.; Chung, Y.-S.; Park, S.-C.; Chang, S.-H.; Youn, H.-J.; Lee, K.-H. High dietary inorganic phosphate increases lung tumorigenesis and alters Akt signaling. Am. J. Respir. Crit. Care Med. 2009, 179, 59-68. [CrossRef] [PubMed]

18. Lin, Y.; McKinnon, K.E.; Ha, S.W.; Beck, G.R., Jr. Inorganic phosphate induces cancer cell mediated angiogenesis dependent on forkhead box protein C2 (FOXC2) regulated osteopontin expression. Mol. Carcinog. 2015, 54, 926-934. [CrossRef] [PubMed]

19. Chudek, J.; Nagy, A.; Kokot, F.; Podwinski, A.; Wiecek, A.; Ritz, E.; Kovacs, G. Phosphatemia is related to chromosomal aberrations of parathyroid glands in patients with hyperparathyroidism. J. Nephrol. 2007, 20, 164-172.

20. Bobko, A.A.; Eubank, T.D.; Driesschaert, B.; Dhimitruka, I.; Evans, J.; Mohammad, R.; Tchekneva, E.E.; Dikov, M.M.; Khramtsov, V.V. Interstitial inorganic phosphate as a tumor microenvironment marker for tumor progression. Sci. Rep. 2017, 7, 41233. [CrossRef]

21. Levan, K.; Mehryar, M.; Mateoiu, C.; Albertsson, P.; Bäck, T.; Sundfeldt, K. Immunohistochemical evaluation of epithelial ovarian carcinomas identifies three different expression patterns of the MX35 antigen, NaPi2b. BMC Cancer 2017, 17, 303. [CrossRef]

22. D'Arcangelo, M.; Brustugun, O.; Xiao, Y.; Choi, Y.; Behrens, C.; Solis, L.; Wang, Y.; Firestein, R.; Boyle, T.; Lund-Iversen, M. 194P prevalence and prognostic significance of sodium-dependent phosphate transporter 2B (NAPI2B) protein expression in non-small cell lung cancer (NSCLC). Ann. Oncol. 2014, 25, iv66-iv67. [CrossRef]

23. Elser, J.J.; Kyle, M.M.; Smith, M.S.; Nagy, J.D. Biological stoichiometry in human cancer. PLoS ONE 2007, 2, e1028. [CrossRef]

24. Camalier, C.E.; Young, M.R.; Bobe, G.; Perella, C.M.; Colburn, N.H.; Beck, G.R. Elevated phosphate activates N-ras and promotes cell transformation and skin tumorigenesis. Cancer Prev. Res. 2010, 3, 359-370. [CrossRef]

25. Papaloucas, C.; Papaloucas, M.; Kouloulias, V.; Neanidis, K.; Pistevou-Gompaki, K.; Kouvaris, J.; Zygogianni, A.; Mystakidou, K.; Papaloucas, A. Measurement of blood phosphorus: A quick and inexpensive method for detection of the existence of cancer in the body. Too good to be true, or forgotten knowledge of the past? Med. Hypotheses 2014, 82, 24-25. [CrossRef] [PubMed]

26. Wulaningsih, W.; Michaelsson, K.; Garmo, H.; Hammar, N.; Jungner, I.; Walldius, G.; Holmberg, L.; Van Hemelrijck, M. Inorganic phosphate and the risk of cancer in the Swedish AMORIS study. BMC Cancer 2013, 13, 257. [CrossRef] [PubMed] 
27. Lacerda-Abreu, M.A.; Russo-Abrahão, T.; Cosentino-Gomes, D.; Nascimento, M.T.C.; Carvalho-Kelly, L.F.; Gomes, T.; Rodrigues, M.F.; König, S.; Rumjanek, F.D.; Monteiro, R.Q.; et al. H(+)-dependent inorganic phosphate transporter in breast cancer cells: Possible functions in the tumor microenvironment. Biochim. Biophys. Acta Mol. Basis Dis. 2019, 1865, 2180-2188. [CrossRef] [PubMed]

28. Mansinho, A.; Ferreira, A.R.; Casimiro, S.; Alho, I.; Vendrell, I.; Costa, A.L.; Sousa, R.; Abreu, C.; Pulido, C.; Macedo, D.; et al. Levels of Circulating Fibroblast Growth Factor 23 (FGF23) and Prognosis in Cancer Patients with Bone Metastases. Int. J. Mol. Sci. 2019, 20, 695. [CrossRef]

29. Li, J.R.; Chiu, K.Y.; Ou, Y.C.; Wang, S.S.; Chen, C.S.; Yang, C.K.; Ho, H.C.; Cheng, C.L.; Yang, C.R.; Chen, C.C.; et al. Alteration in serum concentrations of FGF19, FGF21, and FGF23 in patients with urothelial carcinoma. Biofactors 2019, 45, 62-68. [CrossRef]

30. Kim, W.T.; Bang, W.J.; Seo, S.P.; Kang, H.W.; Byun, Y.J.; Piao, X.M.; Jeong, P.; Shin, K.S.; Choi, S.Y.; Lee, O.J.; et al. Parathyroid hormone is associated with prostate cancer. Prostate Int. 2020, 8, 116-120. [CrossRef]

31. Kato, H.; Ito, N.; Makita, N.; Nangaku, M.; Leung, A.M.; Inoue, K. Association of Serum Parathyroid Hormone Levels With All-Cause and Cause-Specific Mortality Among U.S. Adults. Endocr. Pract. 2022, 28, 70-76. [CrossRef]

32. Palmieri, S.; Roggero, L.; Cairoli, E.; Morelli, V.; Scillitani, A.; Chiodini, I.; Eller-Vainicher, C. Occurrence of malignant neoplasia in patients with primary hyperparathyroidism. Eur. J. Intern. Med. 2017, 43, 77-82. [CrossRef]

33. Mirza, M.A.; Alsiö, J.; Hammarstedt, A.; Erben, R.G.; Michaëlsson, K.; Tivesten, A.; Marsell, R.; Orwoll, E.; Karlsson, M.K.; Ljunggren, O.; et al. Circulating fibroblast growth factor-23 is associated with fat mass and dyslipidemia in two independent cohorts of elderly individuals. Arterioscler. Thromb. Vasc. Biol. 2011, 31, 219-227. [CrossRef]

34. Ministrini, S.; Ricci, M.A.; Daviddi, G.; Scavizzi, M.; De Vuono, S.; D’Abbondanza, M.; Paganelli, M.T.; Boni, M.; Roscini, A.R.; Scarponi, A.M.; et al. Determinants of High Parathyroid Hormone Levels in Patients With Severe Obesity and Their Relationship With the Cardiometabolic Risk Factors, Before and After a Laparoscopic Sleeve Gastrectomy Intervention. Obes. Surg. 2020, 30, 2225-2232. [CrossRef]

35. Coluzzi, I.; Raparelli, L.; Guarnacci, L.; Paone, E.; Del Genio, G.; le Roux, C.W.; Silecchia, G. Food Intake and Changes in Eating Behavior After Laparoscopic Sleeve Gastrectomy. Obes. Surg. 2016, 26, 2059-2067. [CrossRef] [PubMed]

36. Ha, J.; Jo, K.; Lim, D.J.; Lee, J.M.; Chang, S.A.; Kang, M.I.; Cha, B.Y.; Kim, M.H. Parathyroid hormone and vitamin D are associated with the risk of metabolic obesity in a middle-aged and older Korean population with preserved renal function: A cross-sectional study. PLoS ONE 2017, 12, e0175132. [CrossRef] [PubMed]

37. Jiang, S.; Ma, X.; Li, M.; Yan, S.; Zhao, H.; Pan, Y.; Wang, C.; Yao, Y.; Jin, L.; Li, B. Association between dietary mineral nutrient intake, body mass index, and waist circumference in U.S. adults using quantile regression analysis NHANES 2007-2014. PeerJ 2020, 8, e9127. [CrossRef] [PubMed]

38. Hartman, M.-L.; Groppo, F.; Ohnishi, M.; Goodson, J.M.; Hasturk, H.; Tavares, M.; Yaskell, T.; Floros, C.; Behbehani, K.; Razzaque, M.S. Can salivary phosphate levels be an early biomarker to monitor the evolvement of obesity. In Phosphate and Vitamin D in Chronic Kidney Disease; Karger Publishers: Basel, Switzerland, 2013; Volume 180, pp. 138-148.

39. Håglin, L.; Törnkvist, B.; Bäckman, L. Obesity, smoking habits, and serum phosphate levels predicts mortality after life-style intervention. PLOS ONE 2020, 15, e0227692. [CrossRef] [PubMed]

40. Stoian, M.; Stoica, V. The role of disturbances of phosphate metabolism in metabolic syndrome. Maedica 2014, 9, 255-260. [PubMed]

41. Engin, A. The Definition and Prevalence of Obesity and Metabolic Syndrome. Adv. Exp. Med. Biol. 2017, 960, 1-17. [CrossRef]

42. García-Estévez, L.; Cortés, J.; Pérez, S.; Calvo, I.; Gallegos, I.; Moreno-Bueno, G. Obesity and Breast Cancer: A Paradoxical and Controversial Relationship Influenced by Menopausal Status. Front. Oncol. 2021, 11, 705911. [CrossRef]

43. Piiroinen, O.; Kaihola, H.L. Uterine size measured by ultrasound during the menstrual cycle. Acta Obstet. Gynecol. Scand. 1975, 54, 247-250. [CrossRef]

44. Gorczyca, A.M.; Sjaarda, L.A.; Mitchell, E.M.; Perkins, N.J.; Schliep, K.C.; Wactawski-Wende, J.; Mumford, S.L. Changes in macronutrient, micronutrient, and food group intakes throughout the menstrual cycle in healthy, premenopausal women. Eur. J. Nutr. 2016, 55, 1181-1188. [CrossRef]

45. Shanmugalingam, T.; Crawley, D.; Bosco, C.; Melvin, J.; Rohrmann, S.; Chowdhury, S.; Holmberg, L.; Van Hemelrijck, M. Obesity and cancer: The role of vitamin D. BMC Cancer 2014, 14, 712. [CrossRef]

46. Olanbiwonnu, T.; Holden, R.M. Inorganic phosphate as a potential risk factor for chronic disease. Cmaj 2018, 190, E784-E785 [CrossRef] [PubMed]

47. Ritz, E.; Hahn, K.; Ketteler, M.; Kuhlmann, M.K.; Mann, J. Phosphate additives in food-A health risk. Dtsch. Arztebl. Int. 2012, 109, 49-55. [CrossRef] [PubMed]

48. Adams, J. Addressing socioeconomic inequalities in obesity: Democratising access to resources for achieving and maintaining a healthy weight. PLoS Med. 2020, 17, e1003243. [CrossRef] [PubMed]

49. Rauber, F.; Chang, K.; Vamos, E.P.; da Costa Louzada, M.L.; Monteiro, C.A.; Millett, C.; Levy, R.B. Ultra-processed food consumption and risk of obesity: A prospective cohort study of UK Biobank. Eur. J. Nutr. 2021, 60, 2169-2180. [CrossRef] [PubMed]

50. Fiolet, T.; Srour, B.; Sellem, L.; Kesse-Guyot, E.; Allès, B.; Méjean, C.; Deschasaux, M.; Fassier, P.; Latino-Martel, P.; Beslay, M.; et al. Consumption of ultra-processed foods and cancer risk: Results from NutriNet-Santé prospective cohort. BMJ 2018, 360, k322. [CrossRef] [PubMed] 
51. Sim, J.; Smith, N.; Chung, J.; Kalantar-Zadeh, K. Evaluation Of Serum Phosphorus Levels And Obesity. Kidney Res. Clin. Pract. 2012, 31, A74. [CrossRef]

52. Hall, K.D.; Ayuketah, A.; Brychta, R.; Cai, H.; Cassimatis, T.; Chen, K.Y.; Chung, S.T.; Costa, E.; Courville, A.; Darcey, V.; et al Ultra-Processed Diets Cause Excess Calorie Intake and Weight Gain: An Inpatient Randomized Controlled Trial of Ad Libitum Food Intake. Cell Metab. 2019, 30, 67-77.e63. [CrossRef]

53. Hu, F.B. Resolved: There is sufficient scientific evidence that decreasing sugar-sweetened beverage consumption will reduce the prevalence of obesity and obesity-related diseases. Obes. Rev. 2013, 14, 606-619. [CrossRef]

54. Sánchez-Pimienta, T.G.; Batis, C.; Lutter, C.K.; Rivera, J.A. Sugar-Sweetened Beverages Are the Main Sources of Added Sugar Intake in the Mexican Population. J. Nutr. 2016, 146, 1888S-1896S. [CrossRef]

55. Malik, V.S.; Schulze, M.B.; Hu, F.B. Intake of sugar-sweetened beverages and weight gain: A systematic review. Am. J. Clin. Nutr. 2006, 84, 274-288. [CrossRef]

56. Keller, A.; Bucher Della Torre, S. Sugar-Sweetened Beverages and Obesity among Children and Adolescents: A Review of Systematic Literature Reviews. Child. Obes. 2015, 11, 338-346. [CrossRef] [PubMed]

57. Luger, M.; Lafontan, M.; Bes-Rastrollo, M.; Winzer, E.; Yumuk, V.; Farpour-Lambert, N. Sugar-Sweetened Beverages and Weight Gain in Children and Adults: A Systematic Review from 2013 to 2015 and a Comparison with Previous Studies. Obes. Facts. 2017, 10, 674-693. [CrossRef] [PubMed]

58. Ruanpeng, D.; Thongprayoon, C.; Cheungpasitporn, W.; Harindhanavudhi, T. Sugar and artificially sweetened beverages linked to obesity: A systematic review and meta-analysis. QJM: An. Int. J. Med. 2017, 110, 513-520. [CrossRef] [PubMed]

59. Qin, P.; Li, Q.; Zhao, Y.; Chen, Q.; Sun, X.; Liu, Y.; Li, H.; Wang, T.; Chen, X.; Zhou, Q.; et al. Sugar and artificially sweetened beverages and risk of obesity, type 2 diabetes mellitus, hypertension, and all-cause mortality: A dose-response meta-analysis of prospective cohort studies. Eur. J. Epidemiol. 2020, 35, 655-671. [CrossRef]

60. Mullee, A.; Romaguera, D.; Pearson-Stuttard, J.; Viallon, V.; Stepien, M.; Freisling, H.; Fagherazzi, G.; Mancini, F.R.; BoutronRuault, M.C.; Kühn, T.; et al. Association Between Soft Drink Consumption and Mortality in 10 European Countries. JAMA Intern. Med. 2019, 179, 1479-1490. [CrossRef]

61. Amato, D.; Maravilla, A.; García-Contreras, F.; Paniagua, R. Soft-drinks and health. Rev. Investig. Clin. 1997, 49, 387-395.

62. Alkhedaide, A.; Soliman, M.M.; Salah-Eldin, A.E.; Ismail, T.A.; Alshehiri, Z.S.; Attia, H.F. Chronic effects of soft drink consumption on the health state of Wistar rats: A biochemical, genetic and histopathological study. Mol. Med. Rep. 2016, 13, 5109-5117. [CrossRef]

63. Elsherif, M.T.; Tawfik, M.S.; Gomaa, R.S.; elmalkey, n.f. Evaluation of Chronic Cola Consumption Effect on the Liver and Kidney Functions in Adult Male Rats: Role of Serum 25-hydroxyvitamin D. Zagazig Univ. Med. J. 2021, 27, 305-315. [CrossRef]

64. Mazariegos-Ramos, E.; Guerrero-Romero, F.; Rodríguez-Morán, M.; Lazcano-Burciaga, G.; Paniagua, R.; Amato, D. Consumption of soft drinks with phosphoric acid as a risk factor for the development of hypocalcemia in children: A case-control study. $J$. Pediatr. 1995, 126, 940-942. [CrossRef]

65. Mazariegos-Ramos, E.; Rodriguez-Moran, M.; Guerrero-Romero, J.; Paniagua, R. Calcium and phosphate metabolism disorders secondary to consumption of soft drinks with phosphoric acid. Bol. Med.-Hosp. Infant. De Mex. 1995, $52,6$.

66. Fernando, G.R.; Martha, R.M.; Evangelina, R. Consumption of soft drinks with phosphoric acid as a risk factor for the development of hypocalcemia in postmenopausal women. J. Clin. Epidemiol. 1999, 52, 1007-1010. [CrossRef]

67. Guarnotta, V.; Riela, S.; Massaro, M.; Bonventre, S.; Inviati, A.; Ciresi, A.; Pizzolanti, G.; Benvenga, S.; Giordano, C. The Daily Consumption of Cola Can Determine Hypocalcemia: A Case Report of Postsurgical Hypoparathyroidism-Related Hypocalcemia Refractory to Supplemental Therapy with High Doses of Oral Calcium. Front. Endocrinol. 2017, 8, 7. [CrossRef] [PubMed]

68. Tucker, K.L.; Morita, K.; Qiao, N.; Hannan, M.T.; Cupples, L.A.; Kiel, D.P. Colas, but not other carbonated beverages, are associated with low bone mineral density in older women: The Framingham Osteoporosis Study. Am. J. Clin. Nutr. 2006, 84, 936-942. [CrossRef] [PubMed]

69. Ahn, H.; Park, Y.K. Sugar-sweetened beverage consumption and bone health: A systematic review and meta-analysis. Nutr. J. 2021, 20, 41. [CrossRef] [PubMed]

70. Kim, Y.A.; Yoo, J.H. Associations between cola consumption and bone mineral density in Korean adolescents and young adults: A cross-sectional study using data from the Korea National Health and Nutrition Examination Survey, 2008-2011. J. Nutr. Sci. 2020, 9, e56. [CrossRef]

71. Belpoggi, F.; Soffritti, M.; Tibaldi, E.; Falcioni, L.; Bua, L.; Trabucco, F. Results of long-term carcinogenicity bioassays on Coca-Cola administered to Sprague-Dawley rats. Ann. N. Y. Acad. Sci. 2006, 1076, 736-752. [CrossRef]

72. Chazelas, E.; Srour, B.; Desmetz, E.; Kesse-Guyot, E.; Julia, C.; Deschamps, V.; Druesne-Pecollo, N.; Galan, P.; Hercberg, S.; Latino-Martel, P.; et al. Sugary drink consumption and risk of cancer: Results from NutriNet-Santé prospective cohort. BMJ 2019, 366, 12408. [CrossRef]

73. Inoue-Choi, M.; Robien, K.; Mariani, A.; Cerhan, J.R.; Anderson, K.E. Sugar-sweetened beverage intake and the risk of type I and type II endometrial cancer among postmenopausal women. Cancer Epidemiol. Biomark. Prev. 2013, 22, 2384-2394. [CrossRef]

74. Hur, J.; Otegbeye, E.; Joh, H.K.; Nimptsch, K.; Ng, K.; Ogino, S.; Meyerhardt, J.A.; Chan, A.T.; Willett, W.C.; Wu, K.; et al. Sugar-sweetened beverage intake in adulthood and adolescence and risk of early-onset colorectal cancer among women. Gut 2021, 70, 2330-2336. [CrossRef] 
75. Li, Y.; Guo, L.; He, K.; Huang, C.; Tang, S. Consumption of sugar-sweetened beverages and fruit juice and human cancer: A systematic review and dose-response meta-analysis of observational studies. J. Cancer 2021, 12, 3077-3088. [CrossRef]

76. Jatho, A.; Cambia, J.M.; Myung, S.K. Consumption of artificially sweetened soft drinks and risk of gastrointestinal cancer: A meta-analysis of observational studies. Public Health Nutr. 2021, 24, 6122-6136. [CrossRef] [PubMed]

77. Stepien, M.; Duarte-Salles, T.; Fedirko, V.; Trichopoulou, A.; Lagiou, P.; Bamia, C.; Overvad, K.; Tjønneland, A.; Hansen, L.; Boutron-Ruault, M.C.; et al. Consumption of soft drinks and juices and risk of liver and biliary tract cancers in a European cohort. Eur. J. Nutr. 2016, 55, 7-20. [CrossRef] [PubMed]

78. Borges, M.C.; Louzada, M.L.; de Sá, T.H.; Laverty, A.A.; Parra, D.C.; Garzillo, J.M.; Monteiro, C.A.; Millett, C. Artificially Sweetened Beverages and the Response to the Global Obesity Crisis. PLoS Med. 2017, 14, e1002195. [CrossRef] [PubMed]

79. Fulgoni, K.; Fulgoni, V.L., 3rd. Trends in Total, Added, and Natural Phosphorus Intake in Adult Americans, NHANES 1988-1994 to NHANES 2015-2016. Nutrients 2021, 13, 2249. [CrossRef]

80. Beydoun, M.A.; Fanelli-Kuczmarski, M.T.; Beydoun, H.A.; Dore, G.A.; Canas, J.A.; Evans, M.K.; Zonderman, A.B. Dairy product consumption and its association with metabolic disturbance in a prospective study of urban adults. Br. J. Nutr. 2018, 119, 706-719. [CrossRef]

81. Beydoun, M.A.; Gary, T.L.; Caballero, B.H.; Lawrence, R.S.; Cheskin, L.J.; Wang, Y. Ethnic differences in dairy and related nutrient consumption among US adults and their association with obesity, central obesity, and the metabolic syndrome. Am. J. Clin. Nutr. 2008, 87, 1914-1925. [CrossRef]

82. Pereira Dde, C.; Lima, R.P.; de Lima, R.T.; Gonçalves Mda, C.; de Morais, L.C.; Franceschini Sdo, C.; Filizola, R.G.; de Moraes, R.M.; Asciutti, L.S.; Costa, M.J. Association between obesity and calcium:phosphorus ratio in the habitual diets of adults in a city of Northeastern Brazil: An epidemiological study. Nutr. J. 2013, 12, 90. [CrossRef]

83. Ito, H.; Kumagai, T.; Kimura, M.; Koike, S.; Shimizu, T. Dietary Intake in Body Mass Index Differences in Community-Based Japanese Patients with Schizophrenia. Iran. J. Public Health 2015, 44, 639-645.

84. Sciencedaily.com. Common Food Additive Found To Increase Risk And Speed Spread Of Lung Cancer. Amercian Thoracic Society. Available online: https:/ / www.sciencedaily.com/releases/2008/12/081229080851.htm\#: \{\}:text=to\%20the \%20disease.-,New\%20 research \%20in\%20an\%20animal\%20model $\% 20$ suggests $\% 20$ that $\% 20 \mathrm{a} \% 20$ diet, tumors $\% 20 \mathrm{in} \% 20$ individuals $\% 20$ predisposed $\%$ 20to (accessed on 22 December 2021).

85. Neuhouser, M.L. The importance of healthy dietary patterns in chronic disease prevention. Nutr. Res. 2019, 70, 3-6. [CrossRef]

86. Baron, R.M.; Kenny, D.A. The moderator-mediator variable distinction in social psychological research: Conceptual, strategic, and statistical considerations. J. Pers. Soc. Psychol. 1986, 51, 1173-1182. [CrossRef]

87. Kotsis, V.; Martinez, F.; Trakatelli, C.; Redon, J. Impact of Obesity in Kidney Diseases. Nutrients 2021, 13, 4482. [CrossRef] [PubMed]

88. Schipper, H.; Turley, E.A.; Baum, M. A new biological framework for cancer research. Lancet 1996, 348, 1149-1151. [CrossRef]

89. Molina, P.; Gavela, E.; Vizcaíno, B.; Huarte, E.; Carrero, J.J. Optimizing Diet to Slow CKD Progression. Front. Med. 2021, 8, 654250. [CrossRef] [PubMed] 